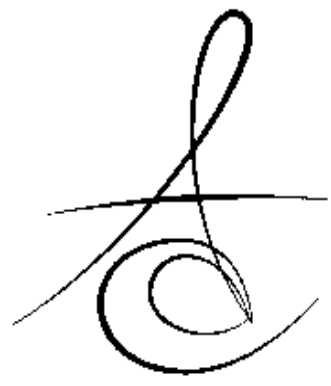

Makale Kodu/Article code: 3561

Makale Gönderilme tarihi: 06.02.2018

Kabul Tarihi: 12.07 .2018

\section{DİŞ HEKİMLİĞİNDE GEN TEDAVİSİ (DERLEME)}

\section{GENE THERAPY IN DENTISTRY (REVIEW)}

\section{öz}

Biyoteknoloji alanındaki gelişmeler, medikal araştırmalarda gen tedavisini ön plana çıkarmış ve günümüz genetik prensiplerinin ağız diş sağlığını geliştirmek için kullanılmasına yol açmıştır. Bu yeni teknolojilerinin diş hekimliği ile buluşmasını; restoratif biyometaryallerin üretiminde kaydedilen bilimsel aşamalar, doku mühendisliği, moleküler biyolojinin kullanımı ve insan genom projesi sağlamıştır. Gen tedavisi, defektli genin özel bir yöntem kullanılarak tedavi edici bir gen ile değiştirilmesi veya tamir edilmesidir. Birçok hastalığın tedavisinde ve genetik bozuklukların düzeltilmesinde kullanılabilmektedir. Gen tedavisinin diş hekimliğinde dentofasiyal uygulama alanları arasında kemik rejenerasyonu, DNA bazlı immunizasyon (çürük ve periodontal hastalıklar), ağrı tedavisi, otoimmun hastalıkların tedavisi ve kanser tedavisi yer almaktadır. Genel olarak araştırmalarda yeni vektör sistemlerinin ve taşıma metotlarının geliştirilmesi, bunların test edilmesi, vektör transdüksiyonunu içeren mekanizmaların açıklığa kavuşturulması ve en iyi sonuç verebilecek yaklaşımların klinik deneylerde kullanılmasına çalışılmaktadır. Geçtiğimiz 15 yılda gen ve ilaç taşıyıcı sistemler için çeşitli vektörler geliştirilmeye çalışılmıştır. Gen tedavisi, diş hekimliği alanında bilimsel bazda önemli etkiye sahiptir. Bu derlemede gen tedavisi metotları, ilgili vektörler, gen tedavisinin diş hekimliğinde klinik etkisi ve konuya ilişkin bilimsel bilgilerin güncellenmesi amaçlanmıştır.

Anahtar Kelimeler: Diş hekimliği, Genetik, Gen tedavisi, Genetik vektörler

\section{ABSTRACT}

Advances in biotechnology have brought gene therapy to a very important and active area of medical research and currently genetic principles are being applied along to improve oral health. Scientific advances in restorative biomaterials, tissue engineering, molecular biology and the human genome project provide the basis for the introduction of new technologies into dentistry. Gene therapy is a particular method by which missing or defective genes are replaced or repaired by normal genes. It can be used to treat wide range of diseases and correct genetics disorders. In dentistry the application of gene therapy to dentofacial problems includes bone regeneration, DNA based immunization (for caries and periodontal disease), pain, for treating auto immune disease and cancer. The general approach is to develop new vector systems and delivery methods, test them, uncover the mechanisms involved in vector transduction, and use the most promising approaches in clinical trials. For the past 15 years various vectors have been designed for improved gene and drug delivery. This field is having significant impact on topics related to dental practice. The aim of this review is to provide an update on gene therapy methods, its clinical implication in dentistry and scientific information associated with gene therapy.

Key Words: Dentistry, Genetics, Gene therapy, Genetic vectors

\footnotetext{
* İstanbul Üniversitesi Diş Hekimliği Fakültesi Pedodonti AD. İstanbul
} 


\section{Gíriş}

Genler, spesifik yaşamsal proteinlerin yapımını kodlayan fonksiyonel kalıtımsal ünitelerdir. Genlerde meydana gelen değişikliklerin sonucunda kodlanan proteinlerin normal fonksiyonlarını devam ettirememesi çeşitli genetik hastalıklara yol açmaktadır. ${ }^{1}$

Gen tedavisi, hastalıkların tedavi edilmesi veya önlenmesi amacı ile bireyin hücrelerine genlerin yerleştirilerek mutant allellerin fonksiyonel alleller ile yer değiştirilmesinin, ${ }^{2-3}$ bir anlamda DNA-bazlı immunizasyonun sağlanmasıdır. ${ }^{4}$

İnsan genomu yaklaşık olarak 3 milyar nükleotidin meydana getirdiği 100.000 alleli kapsayan 46 kromozomdan meydana gelmektedir. Bu kromozomların transkripsiyonu yaklaşık olarak 6.000 proteinin sentezi için gerekli olmaktadır. Proteinler ise insan vücudunda trilyonlarca hücrenin harekete geçmesini ve yaklaşık olarak 4.000 anatomik yapının oluşmasını sağlamaktadırlar. Mutasyon nedeni ile büyüme ve gelişimin farklı yönlerini etkileyebilen kalıtsal durumlar veya sendromlar gelişebilmektedir. ${ }^{5}$ Bilinen 5.000 genetik sendromun 700'den fazlası baş boyun bölgesi ile ilişkili olmaktadır. Ülkemizde yapılan bir çalışmada 6 yıllık dönemdeki genel konjenital anomali prevalansı doğumlarda \%3.6 olmak üzere \%28.6'sını baş boyun bölgesindeki anomaliler oluşturmaktadır. ${ }^{6}$ Mutasyonun baş boyun bölgesinde defekte yol açtığı olgularda transkripsiyon faktörleri, büyüme faktörleri ve ilgili reseptörleri, hormon reseptörleri, hücre adezyon molekülleri, G proteinleri, enzimler, vektörler ve kollajenleri içeren farklı kategorilerdeki gen veya proteinler etkilenmektedir. ${ }^{5}$

\section{Gen tedavisi çeşitleri}

Gen tedavisi, değişikliğe uğrayan hücrelerin tipine göre temel olarak iki ana sınıfa ayrılmaktadır:

2.1. Germ hücre serileri: Sperm veya yumurta gibi hücreler üzerine yapılan gen tedavisi ile elde edilen değişiklikler nesiller boyunca aktarılmaktadır. ${ }^{7,8}$ Gamet, zigot veya erken dönemde embriyonel değişiklikler yapılabilmektedir. ${ }^{9}$ Gelecek nesilleri etkileyebilmesi nedeni ile germ hücre tedavisi birçok ülkede etik olarak yasaklanmıştır. ${ }^{8}$ Yalnızca mitokondrial hastalıklar için çekirdek gen transferi etik açıdan kabul görmektedir. Bu amaçla in vitro fertilizasyonu takip eden süreçte (dört hücreli aşamada) tüm hücrelerin çekirdekleri izole edilerek, mitokondri DNA'sı çekirdeği çıkarılmış yumurta hücrelerine yerleştirilmektedir. Bu yöntem klonlama olarak da değerlendirilmektedir. ${ }^{10} \mathrm{Bu}$ yaklaşımın genetik hastalıklarda teorik olarak oldukça etkili olduğu belirtilmektedir. ${ }^{7}$

2.2. Somatik hücre serileri: Bu yöntemde amaç, hastalığın düzelmesine yönelik hedef hücrelerde veya dokularda genetik değişikliğe yol açmaktır. ${ }^{10} \mathrm{Ge}-$ lecek nesilleri etkilemeden sadece bireyin genomunda değişiklik meydana getirilmektedir.7,8 Günümüzde yapılan gen tedavisi protokolleri bu gruba girmektedir.

Somatik hücre serileri üzerinde yapılan gen tedavileri dört grup altında incelenebilmektedir:

1) Gen ilavesi: Sorunlu genin işlevsel bir kopyasının eklenmesi amaçlanmakta, mutant gen kaldırımadan fonksiyonel gen ilave edilmektedir.

2) Gen değişimi: Mutant genin fonksiyonel kopyası ile değiştirilerek mutasyonun in situ düzeltilmesidir.

3) Gen ekspresyonunun baskılanması: Hedef patojenin fonksiyonunun baskılanmasıdır.

4) Spesifik hücrelerin öldürülmesi: Gen ile yönlendirilmiş enzim, ön ilaç tedavisi adı da verilmektedir. Ön ilaç vücuda verilirken, ön ilacı aktifleyen enzimi kodlayan gen de hastalıklı hücrelere aktarılmaktadır. ${ }^{10}$

\section{Genlerin hedef hücreye aktarılması}

Laboratuvar ortamında (ex vivo) veya hasta vücudunda (in vivo) gerçekleştirilebilmektedir.

3.1. Ex vivo gen tedavisi: Hastadan alınan hücrelerin hücre kültüründe çoğaltılarak, genin klonlanmasını ve transfeksiyon aşamalarını içermektedir. ${ }^{11,12}$ İmmun sistemin yanıtı açısından hastanın otolog hücreleri tercih edilmektedir. ${ }^{10}$ Yaygın olarak kullanılmaktadır. $^{7}$

3.2. In vivo gen tedavisi: Alıcı hücrelerin in vitro kültürünün yetersiz olduğu veya hücre kültürü yapılan hücrelerin hastaya naklinin etkili bir biçimde yapılamadığı durumlarda tercih edilmektedir. ${ }^{10}$ Hastanın kendi vücuduna ait hücreleri bu teknikte kullanılmamaktadır. ${ }^{7}$ Gen aktarımı için kullanılan vektörün sadece hedef hücrelerde tanınması planlanmaktadır. ${ }^{10}$

\section{Gen tedavisinde vektörler}

Gen tedavisi çalışmalarında hastalığa yol açan anormal genin yerini alacak olan normal genin hastanın hedef hücresine taşınabilmesi için vektörler (taşıyıcılar) kullanılmaktadır. ${ }^{13}$ Kullanılan başlıca vektörler aşağıda özetlenmiştir:

4.1. Viral vektörler: Konağa bağlanan virüslerin tümü, replikasyon siklüslarının bir parçası olarak kendi genetik materyallerini konak hücrelerine

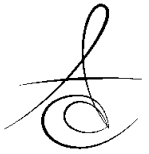


tanitırlar. $^{14}$

Kendi aralarında 2'ye ayrılabilmektedirler:

1- Nonlitik: Virion üreten ve konak hücre yapısını bozmayan virüslerdir. Ör: Adenovirüsler ve lentivirüsler.

2- Litik: Virion üreten ve konak hücreyi yok eden virüslerdir. Ör: İnsan adenovirüsü ve herpes simpleks virüsler. ${ }^{15}$

Retrovirüsler: Gen tedavisinde kullanılan ilk virüslerdir. ${ }^{7}$ RNA tipinde genetik materyal taşırlar ve viral CDNA üreten revers-kriptaz enzimine sahiptirler. ${ }^{11,16}$ Transfekte ettikleri hücrelerin sitoplazmalarında taşıdıkları nükleoprotein kompleksleri, viral RNA genomundaki revers-kriptaz enzimi ile oluşan CDNA'yı, konak hücresinin kromozomunda rastgele bir noktaya girişini sağlamakla görevlidirler. Bu erişim sadece hücre bölünmesi aşamasında çekirdek membranı kaybolduğunda gerçekleşebilmektedir. Retrovirüsler yalnızca bölünmekte olan hücreleri transfekte edebilmektedirler.

Retrovirüslerin gag, pol ve env olmak üzere üç adet transkripsiyon ünitesi bulunmaktadır. Vektörlerdeki gag, pol ve env genleri çıkarılarak bu bölgelere terapötik gen klonlanmaktadır. Bu vektörlerin DNA aktarım kapasitesi yüksek olmaktadır. Ancak mutasyon riski nedeni ile çalışmalar farklı vektörlere yönelmiştir. $^{10}$

Adenovirüsler: Çift sarmallı DNA virüsleridir. Gen tedavisinde vektör olarak genellikle adenovirüs tip 2 (Ad2) ve adenovirüs tip 5 (Ad5) kullanılmaktadır. ${ }^{11,15}$ Retrovirüslerden daha fazla üretilebilmektedir. Geniş doku tropizmi ve düşük patojenite göstermesi başıca avantajlarındandır. Ancak uzun süreli ekspresyon sağlayamamaktadır. Retroviral vektörlere benzer olarak adenoviral vektörlerin üretilebilmesi için yardımcı hücrelere ihtiyaç duyulmaktadır. Ad2 ve Ad5 serotiplerinin geniş doku tropizmi göstermesi, hedeflenmeyen dokularda da gen ekspresyonuna neden olacağından dolayı sistemik kullanımları sakıncalı olmaktadır. ${ }^{10}$ Bu virüslerde karşılaşılan en büyük problem ise yüksek immunojenite bildirilmektedir. ${ }^{7}$ Bu vektörlere karşı nötralizan antikorların gelişmesi, tekrarlayan uygulamaları sınırlamaktadır. Bu problemi çözebilmek için immunsupresiflerin kullanılması ve tekrarlayan uygulamalarda farklı serotiplerden ve hayvansal kaynaklardan yararlanılması gündeme gelmiştir. ${ }^{10}$

Adeno-ilişkili virüsler: Tek sarmallı DNA virüsleridir. Replikasyonları için adenovirüslerin veya herpes virüslerin yardımına intiyaç duymaktadırlar. Yaygın olarak serotip 2 kullanılmaktadır. Yaygın doku tropizmi göstermektedirler. Patojenik olmayan modifiye edilmemiş serotip 2, insan hücrelerinde 19. Kromozomun q13.3-qter bölgesine entegre olarak yaklaşık $\% 100$ oranında latent transfeksiyona yol açmaktadır. ${ }^{7,10,11}$ Böylece uzun süreli gen ekspresyonu sağlayabilmektedirler. Genomu küçük olduğundan kısa DNA dizilerini taşıyabilmekte, ayrıca yüksek titrelerde üretilememektedir. Bireyde immun yanıt oluşturma potansiyeli de bulunmaktadır. ${ }^{10}$

Herpes simpleks virüsleri: Çift sarmallı DNA genomuna sahip nörotropik bir virüstür. Kromozoma entegre olamamakta, ancak duyusal ganglionlarda ömür boyu latent enfeksiyon oluşturmaktadırlar. ${ }^{10,11}$ Gen taşıma kapasitesinin yüksek olması avantaj sağlamaktadır. Sistemik enfeksiyon ile karşılaşılması durumunda antiherpetik ilaçlar ile viral replikasyon durdurulabilmektedir. Virüsün latent faza geçmesi ile birlikte terapötik gende de inaktivasyon olmaktadır. ${ }^{10}$

4.2. Non-viral vektörler: DNA'nın sentetik, doğal veya fiziksel güçler ile hücreye aktarılmasını sağlamaktadırlar. ${ }^{4}$ Üretimlerinin kolay olması, ucuz olmaları, taşıma kapasitelerinin fazlalığı ve biyogüvenilirliğinin yüksek olması nedeni ile tercih edilmektedirler. Ancak düşük gen aktarımı etkinliği ve kısa süreli ekspresyon meydana getirmesi dezavantajlarını oluşturmaktadır. ${ }^{10}$ Genel olarak viral vektörlere göre daha az toksik ve immunojeniktirler. ${ }^{4}$

Kompleks halinde olmayan DNA: Viral olmayan transfeksiyon yöntemleri arasında en basiti olarak bilinmektedir. Ancak diğer yöntemler ile karşılaştırıldığında ekspresyon oranı oldukça düşük kalmaktadır. ${ }^{17}$

Oligonükleotidler: Sentetik oligonükleotidler gen tedavisinde hastalık süreci ile ilişkili genleri inaktive etmek amacı ile kullanılmaktadırlar. ${ }^{18}$

Lipopleksler ve polipleksler: Lipid ile kaplanan plazmid DNA'ları misel veya lipozom gibi düzenli yapılar oluşturmaktadırlar. DNA ile birleştiklerinde bu organize yapılar lipopleks adını almaktadıllar. Anyonik (negatif yüklü), nötral ve katyonik (pozitif yüklü) olmak üzere üç tipi bulunmaktadır. ${ }^{19}$

Hibrit yöntem: Gen aktarımında kullanılan yöntemlerin kısa süreli sonuçlar vermesi nedeni ile iki veya daha fazla tekniğin kombinasyonunun kullanımı düşünülmüştür. Örneğin, inaktive edilmiş HIV veya influenza virüsü ile kombine olan lipozomlara virozom adı verilmekte ve solunum yolu epitel hücreleri üzerine

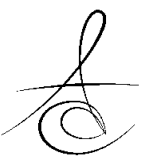


sadece viral veya sadece lipozomal yöntemlerden daha fazla etki göstermektedir. Farklı viral vektörler katyonik lipidler ile kombine edilebilmekte veya virüslerin hibrit kullanımı söz konusu olabilmektedir. ${ }^{20}$

Dendrimerler: Küre formunda çok dallı makromoleküllerdir. Katyonik dendrimerler elde edilebilmekte, bu da pozitif yüklü bir yüzey sağlamaktadır. ${ }^{21}$

4.3. Fiziksel Yöntemler: Hücre içi gen transferi için hücre membranını geçecek fiziksel bir güç sağlamaktadırlar. Yöntemin basit oluşu en önemli avantajıdır.

İğne enjeksiyonu: DNA'nın dokuya enjektör vasıtası ile direkt taşınabildiği en pratik gen transferi metodudur. DNA aşılarında yaygın kullanılmaktadır. Gen transferi etkinliğinin düşük olması ise dezavantajıdır. ${ }^{22}$ Plazmid aşılar veya canlı, viral vektörlerin kullanıldığı aşılar olmak üzere ikiye ayrılırlar.

Plazmidlerin kullanıldığı aşılarda DNA'nın üreme kapasitesi yoktur, ancak plazmidler üreyebilmektedir. Plazmidlerin bu özelliği, hayvanlara inokülasyon ve antikor oluşturma aşamasında patojenle karıştırılmasına sebep olmaktadır. Plazmidlerin dezavantajı olarak bazı olgularda onkogenezise yol açabilmesi gösterilmektedir.

İkinci grupta enfeksiyöz potansiyeli olan ancak hastalığa yol açmayan çeşitli DNA veya RNA virüsleri ile bakteriler yer almaktadır. Bu vektörler vücuda girdikten sonra hümoral veya hücresel immun yanıtı uyarmaktadırlar.

DNA aşılarının uygulama yöntemleri arasında nazal enjeksiyon, intramuskuler enjeksiyon ve gen tabancası yer almaktadır. ${ }^{23}$

Balistik DNA enjeksiyonu: Partikül bombardımanı veya gen tabancası olarak da adlandırılabilmektedir. Memeli hücrelerine hem in vitro hem de in vivo gen transferine olanak sağlamaktadır. Ancak bu yöntemle aktarılan genler geçici süre ile eksprese olmaktadır. ${ }^{15,22}$

Elektroporasyon: Elektrik uyarıları ile hücre membranında meydana getirilen porlar vasıtasıyla gen aktarımı sağlayan basit bir uygulamadır. Süspansiyon halindeki solüsyonlarda daha iyi sonuçlar vermekte, ancak katı dokulara da uygulanabilmektedir. ${ }^{17,22}$

Sonoporasyon: Ultrason teknolojisi ile hücre membranı permeabilitesinde geçirgenliği sağlayarak hücreye DNA aktarımını gerçekleştirmektedir. Gen aktarımının yanında bu etki yalnızca ultrason uygulanan bölge ile sınırlı kalmaktadır. ${ }^{23}$ Literatürde sonoporas- yon ile diş pulpasına gen aktarımı yer almaktadır. ${ }^{24}$

Lazer destekli yöntem (fotoporasyon): Tek bir lazer atışı ile hücre membranında yer alan porları geçici olarak açarak DNA girişine olanak sağlamaktadır. Bu yöntem ile elde edilen transgen ekspresyonu elektroporasyon yöntemi ile benzerlik göstermektedir. ${ }^{22}$

Manyetofeksiyon: Transfeksiyon amacı ile manyetik bir alan yaratılmaktadır. Demir oksitten yapılan ve katyonik lipit veya polimerle kaplanmış manyetik nanopartiküller, elektrostatik etkileşimler sonucunda DNA ile kompleks bir yapı getirmektedir. Manyetik partiküller, hedef hücreler dış ortamda yaratılan manyetik alan ile yönlendirilmektedir. ${ }^{22}$

\section{Diş hekimliğinde gen tedavisi} uygulamaları

5.1. Kemik ve periodontal doku rejenerasyonu: Travma, neoplazi, rekonstrüktif cerrahi, konjenital defektler ve periodontal hastalıklar sonucunda kemik kaybı meydana gelebilmektedir. ${ }^{11}$ Gen tedavisi ile terapötik seviyede, lokalize ve devamlı olarak bu proteinlerin ekspresyonu amaçlanmaktadır. $\mathrm{Bu}$ alanda gen tedavisinin güvenilir, basit ve hesaplı olduğu belirtilmektedir.

Baş boyun bölgesinde kemik dokusunun tamir ve rejenerasyonunda, dişleri destekleyen yapıların rejenerasyonunda, implant uygulamalarında ve tükürük bezi ile ilgili bozuklukların tedavisinde gen tedavisi çaışmaları yapılmaktadır. Gen tedavisinde amaç vektörlerin kullanılması ile doku büyümesi ve tamir sürecinde yer alan destek elemanlarının yapılandırılmasıdır. In vivo ortamda baş boyun bölgesinde doku mühendisliği ile gen tedavisinin birlikte kullanımı sinerjistik etki göstererek dokuların tamir ve rejenerasyon kapasitesini artıracaktır. $^{25}$

Doku mühendisliğinin genel stratejisi, büyüme faktörü gibi terapötik proteinler ile rejeneratif sahayı desteklemektir. ${ }^{26}$ Kemik dokusunda rejenerasyonun başarılı olabilmesi için osteoindüksiyon, osteoblastların farklılaşması ve osteokondüksiyon gereklidir. ${ }^{11}$ Kemik, kıkırdak, diş, eklem gibi mineralize dokularda ve periodontal defekt bölgelerinde gen tedavisi incelendiğinde örneğin kemik morfogenetik proteinlerin tamir sürecine yardımcı olduğu görülmektedir. ${ }^{11,25} \mathrm{Bu}$ amaçla kullanılan başlıca bileşenler; in vivo ve ex vivo kemik formasyonunu tek başına indükleme kapasitesine sahip olan kemik morfogenik proteinleri (BMPs: bone morphogenetic proteins), trombosit kaynaklı büyüme 
faktörü (PDGF: platelet-derived growth factor), fibroblast büyüme faktörü (FGF: fibroblast growth factor), trombositlerde ve kemik dokuda bulunan transforme edici büyüme faktörü-beta (TGF-beta: transforming growth factor-beta), paratiroid hormon, anjiogenezisi indükleyen vasküler endotelyal büyüme faktörü (VEGF: vascular endothelial growth factor), diş formasyonunu stimüle eden runt-ilişkili transkripsiyon faktörü (RUNX2: runt-related transcription factor)/gen çekirdeği bağlayıcı faktörü a-1 (Cbfa1: gene corebinding factor a-1) ve osteriks içeren transkripsiyon faktörleri, kemik ve diğer mineralize dokularda bulunan kemik sialoproteini, dentin sialofosfoproteini, matriks Gla proteini ve osteopontin içeren ekstrasellüler matriks proteinleridir. ${ }^{11}$

Gen tedavisinde yukarıda belirtilen proteinlerin kombinasyonlarının kullanımı da önerilmiştir. Büyüme ve farklılaşma faktörlerinin ardışık gen ekspresyonu ya da birçok genin ekspresyonunu içeren tamamlayıcı sinyaller ile osteopregenitör popülasyonu artırıp, anjiogenezis ve kondrogenezis gibi osteogenezisin belirli evrelerini kontrol eden faktörlerin kombinasyonlarını içermektedir. ${ }^{11}$ Zhu ve ark. $^{27}$ adenovirüslerde kemik morfogenik proteini (BMP: bone morphogenetic protein) BMP-2, -4 ve -7'nin in vitro şartlarda osteoblastik farklılaşma ile in vivo şartlarda kemik formasyonunu sinerjik stimülasyonlar ile başlattığını göstermiştir. BMP-2 geninin adenoviral transferi (Ad/BMP-2: adenoviral transfer of the BMP-2 gene) ya da Ad/BMP7 ile indüklenen hücrelerin sadece BMP aktarılan hücrelerden daha aktif olduğunu belirtmişlerdir. Cheng ve ark. ${ }^{28}$ Ad/BMP-2/-7'nin Ad/BMP-4 ve -7'den daha güçlü alkalane fosfataz (ALP) indükleyici aktiviteye sahip olduğunu rapor etmişlerdir. BMP-4 ve laktikoglikolik asit içeren VEGF ile şifrelenmiş ve kondanse edilmiş plasmid DNA kombinasyonu içeren kemik iliği hücrelerinin kullanıldığı bir çalışmada, multiple genlerin kemik iyileşmesini arttırdığı belirtilmiştir. Yang ve ark. ${ }^{29}$ mezenkimal hücrelerde RUNX2 faktörü ve BMP'nin adenoviral gen kombinasyonunun sinerjistik olarak in vitro kemik farklılaşmasını ve in vivo kemik formasyonunu uyardığını göstermişlerdir. Özet olarak Ad/BMP'lerin osteogenik aktiviteyi artırdığı açıkça gösterilmektedir. Ad/BMP'lerin yol açtığı artırılmış biyolojik aktivite sayesinde gen aktarımı formülasyonlarının kemik yenilenmesini daha düşük viral titrelerde başarabildiği görülmektedir. ${ }^{11}$

Diş hekimliğinde PDGF kodlayan rekombinant adenoviral vektörlerin kullanımı ile ilgili yapılan erken dönem çalışmalarda, bu viral vektörlerin periodonsiyumdan izole edilen hücrelere (ör. osteoblast, sementoblast, periodontal ligament hücreleri, gingival fibroblastlar) transdüksiyon potansiyelinin olduğu görülmüştür. ${ }^{30}$ Sonraki araştırmalarda PDGF-a'nın devamlı olarak eksojen aktarımı ile sementoblastlarda mineral formasyonu görüldüğü; ${ }^{31}$ direkt in vivo PDGF-B gen transferi ile geniş periodontal defektlerde doku rejenerasyonunun stimüle edildiği ${ }^{29}$ ex vivo ortamda PDGF genlerinin ekspresyonunun gingival yaralarda 10 güne kadar uzayan etki gösterdiği yer almıştır. ${ }^{32}$

BMP ile ilgili çalışmalarda; in vitro ve in vivo ortamda Ad/BMP-7 geni transferinin kemik formasyonunu sağladığı; ${ }^{33}$ direkt in vivo ortamda kollajen jel taşıyıcısında Ad/BMP-7 geni aktarımının dental implantların etrafındaki alveol kemiği defektlerinde başarılı rejenerasyon sağladığı bildirilmektedir. ${ }^{34}$

Oral ve maksillofasiyal cerrahide gen tedavisinin, hayvan deneylerindeki sonuçlarının incelendiği 2017 yılında yayımlanan bir sistematik derleme ve meta-analizde; preklinik çalışmalarda büyük ilerlemelerin kaydedildiği ancak tükürük bezi ve kraniyofasiyal defektlerde halen klinik deney aşamasında kaldığı belirtilmiştir. ${ }^{35}$

Ayrıca hipofosfatazi gibi defektli kemik mineralizasyonu ve non-spesifik alkalen fosfataz aktivitesi bulunan fare deneylerinde gen tedavisinin genel durumu iyileştirdiği, alveol kemiğinde belirgin derecede ve sementte orta derecede yapım sağladığı bildirilmiştir. ${ }^{36}$

5.2. Diş çürüğü: Evrensel olarak toplum sağlığının major hedefi etkili ve güvenilir aşıların geliştirilmesidir. Diş hekimliği alanında ise hedef, aşılama yöntemi ile çürük ve periodontal hastalıkların eradike edilmesidir. Etkili bir immunojenik strateji olarak DNA aşılarının geliştirilmesi ile immun yanıtın indüklenmesi hedeflenmektedir. DNA aşıları viral aşılar ile karşılaştırıldıklarında ucuz, stabil, ve daha güvenilirdirler. ${ }^{37}$ Bunun yanı sıra antijen ve immunostimülatör dizileri kodlayan genlerin entegre edilebilmesi yönünden esneklik sağlarlar. İntramuskuler aşılar yaygın olarak kullanılmakta ancak enfeksiyon ajanlarının vücuda girdiği mukozal bölgelerde lokal immunite sağlamakta başarısız olmaktadırlar. ${ }^{38}$ DNA aşılarının yapıldığı nazal mukoza ise hem sistemik hem mukozal immun yanıtın uyarılmasında etkili bir bölgedir; ${ }^{39-41}$ kolay ulaşılabilir olması, oral yolun kullanımına göre düşük enzim

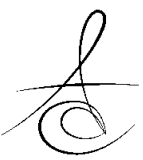


dağııımı göstermesi ve immun hücre yoğunluğu da özelliklerindendir; sıklıkla nazal ilişkili lemfoid doku (NALT: nasal associated lymphoid tissue) olarak adlandırımaktadır. ${ }^{42}$

DNA aşıSı spesifik bir gen içermektedir. $S$. mutans için kullanılan DNA aşılarında ise immunizasyonu sağlamak için, mekanik veya kimyasal lizis yapılmakta ve antijenik proteini kodlayan genetik materyal yer almaktadır. ${ }^{43}$ DNA aşıları ile elde edilen immun yanıt, antijen sunan hücrelerin (APCs: antigen presenting cells) aktivasyonu ile başlatılmaktadır. ${ }^{44}$ Genetik immunizasyon sonrası, DNA aşıları direkt olarak in vivo ortamda somatik hücreleri transfekte edebilmektedir. APCs, transfekte edilen hücreler tarafından eksprese edilen antijenleri yakalayarak, onları işlemekte ve rejyonel lenfoid organlarda yer alan $\mathrm{T}$ lenfositleri gibi MHC (major histocompatibility complex) yoluna sunarak antijene özgü $T$ hücreleri aktive edilmektedir. ${ }^{45}$ Geleneksel aşılara göre DNA aşılarının üstün özellikleri arasında kolay hazırlanması, etkin immun yanıt oluşturması, $T$ ve $B$ lenfositlerini stimüle ederken stabil olması ve sürekli antijen ekspresyonu göstermesi sayılabilmektedir. Ayrıca uygulama ve saklama koşullarının daha güvenli olduğu, modifikasyon ve geliştirilme potansiyelinin de bulunduğu belirtilmektedir. ${ }^{46}$ Xu ve ark. (44) pGJA-P/VAX olarak bilinen çürüğe karşı DNA aşısını geliştirmişlerdir. Yapılan çalışmalarda fareler üzerinde plazmid pGJA-P/VAX DNA aşısı kullanımı ile AL/CS/DNA'nın immunizasyon sonrası güçlü mukozal immun yanıt oluşturduğu gösterilmiştir. ${ }^{47}$

5.3. Baş boyun bölgesi kanserleri: Tümörlerde gen tedavisinin uygulanmasının üç amacı bulunmaktadır. Birincisi, immunomodülatör tedavi ile in vivo şartlarda tümör hücrelerinin immun sisteme görünürlüğünün artırıması veya ex vivo şartlarda spesifik gen ekspresyonu ile etkili hücrelerin modifiye edilmesidir. İkincisi, selektif olarak seçicilik gösteren ve kanser hücrelerini yok eden onkolitik virüslerin geliştirilmesidir. Üçüncüsü, herpes simpleks timidin kinaz gibi intihar genlerinin kanserli hücrelere tanıtılması yolu ile asiklovir gibi antiviral ilaçların duyarlılığının artırılmasıdır. $^{25}$

"Gen ilavesi"nde hücrenin fonksiyonunun geri kazandırıması amacı ile gen veya genin bir kopyası genomun içine yerleştirilmektedir. Oral skuamoz hücreli karsinom için p53, p21 ve p16 mutasyonları tanımlanmışır. Çalışmalarda p53'ün hücre siklusu ve apoptozunu düzenlemesi nedeni ile, karsinoma hastalarında adenoviral bir vektör ile p53 geni primer tümöre enjekte edilmiştir. ${ }^{28}$ Yapılan bir randomize kontrollü deneyde, radikal tümör rezeksiyonu sonrası yara bölgesine enjekte edilen ve radyoterapi ile kombine uygulanan rekombinant adenoviral insan p53 (rAd-p53) gen tedavisinin oral kanser rekürrensinden koruduğu, bu yöntemin etkili ve güvenilir olduğu bildirilmiştir. ${ }^{48}$

Kanser tedavisine yönelik gen tedavisi çalışmalarında, genetik bozukluklarda bu bozukluğun ekspresyonunu önleyebilen spesifik bir terapötik genin kullanımına "antisense" tedavisi adı verilmektedir. Böylece onkojen ekspresyonunun inhibisyonu ile tümörün fenotipini değiştirerek gelişimini durdurması amaçlanmaktadır. ${ }^{49}$

Altta yatan genetik defektin düzeltilmesi yerine direkt veya indirekt olarak kanserli hücrelerin yok edilmesini amaçlayan gen tedavisi "kriyoredüktif gen tedavisi" adını almaktadır. Böylece hücreye yerleştirilen genin ön ilacı (prodrug), sitotoksik ilaç tarafından aktiflenmesini sağlamaktadır. ${ }^{50}$

"İmmunolojik gen tedavisi", oral kanser hücrelerini içeren tümör hücrelerine karşı immunolojik potansiyelinin artırımasını veya hastanın immun yanıtının tümör ogmentasyonunu içermektedir. Sitokinler veya immun regülatör hücreler, HNSCC hücrelerine tanitılarak vücudun immun yanıtını tümör hücrelerine yönlendirirler. Sitokin gen aktarımı in vivo ortamda vücuttaki tümör hücrelerine veya immun hücrelere transfekte edilebilmekte, ya da ex vivo olarak transfeksiyon amacı ile vücuttan hücreler alınır ve tekrar vücuda aktarımaktadır. Melanoma, lenfoma ve bazı virüs kaynaklı malinitelerde immuntedavi çalışmaları devam etmektedir. ${ }^{11,51}$ Replasman gen tedavisinde kullanılan rekombinant adeno-ilişkili virüslerin antitümör aşısında kullanımı da incelenmiştir. Stell ve ark. oral ve intramuskuler yoldan yapılan adeno-ilişkili virus (AAV: adenoassociated virus) serotip 5 ve 6 antitümör aşısı ile sıçanlarda göğüs kanseri üzerine yaptıkları araşıırmada AAV5-neu ve AAV6-neu aşılarının NEU antijenine karşı humoral ve hücresel immun yanıt oluşturduğunu saptamışlardır. Hayvanların \%80'inde aşılamadan 120 ve 320 gün sonra uzun süreli olarak tümörden korunduğunu belirtmişlerdir. ${ }^{52}$

Gen tedavisi, oral kanser ve diğer kronik hastaIıkların tedavisinde günümüzdeki yöntemlere göre daha etkili ve mortalite oranı düşük olduğu öngörülen, henüz

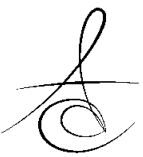


yeni ortaya çıkan bir tıp alanıdır. Gelecekte gen tedavisinin kemoterapi ve immünoterapi ile kombinasyonunun oldukça başarılı sonuçlar vereceği düşünülmektedir. ${ }^{53}$

5.4. Tükürük bezlerine gen transferi: Farmakolojik yan etkiler, radyasyon tedavisi veya Sjögren sendromu gibi otoimmun hastalıklar nedeni ile tükürük bezi fonksiyonunu kaybedebilmektedir. ${ }^{25}$ Bilim adamları fonksiyonel olmayan tükürük bezi dokusunun direkt tamiri yerine, parotis bezine doku mühendisliği ile elde edilen tükürük bezinin implante edilmesini araştırmaktadırlar. ${ }^{54} \mathrm{Bu}$ amaçla parotis gibi büyük tükürük bezinin ana boşaltım kanallarına retroduktal kanal yoluyla yeni bir gen transfer edilmektedir. ${ }^{55}$ Duktal epitelyal hücreler, asiner epitelyal hücrelerden farklı olarak sıvı sekresyonu yapamamaktadırlar. Araştırmacıların in vitro ortamda asiner hücreleri izole edememeleri ve geliştirememeleri nedeni ile duktal hücre popülasyonunun modifiye edilmesi için gen tedavisi uygulanmaktadır. ${ }^{25}$ Yapılan bir çalışmada ek bir vektör sistem olmadan tek başına sonoporasyonun, tükürük bezi proteomları üzerine minimal etki edebildiği gösterilmiştir. ${ }^{56}$

5.5. Keratinositlere gen transferi: Keranitositler oral mukozada yer almaktadırlar. Keratinositlere gen transferi, spesifik bir hastalığı normal protein ya da enzim yolu ile düzelten genin keratinositlere enjekte edilmesi işlemidir. Lokal doku bozukluklarında uygulanan gen tedavisinde ve sistemik gen terapötikleri için bu hücrelerin özellikleri uygundur. ${ }^{57}$ Keratinositler, keratinositlerdeki genetik defektin sebep olduğu cilt hastalıklarının yanında sistemik hastalıkların tedavisinde gen tedavisinin hedef hücresi olarak önemli potansiyele sahiptirler. Henüz klinik deneylerde test edilmemiş olmasına rağmen, sistemik döngüler içindeki faktör 9 ve insan büyüme hormonu gibi faktörlerin kullanıldığı keratinositleri içeren hayvan modelleri mevcuttur. ${ }^{58}$ Transgen içeren keratinositler tarafından kan dolaşımına taşınan faktörlerin verimli ve devamlılık gösteren bir uygulaması henüz başarılı olmamıştır. Sürekli zaman aralıklarında istenilen faktörler enzimler ve hormonları yeterli seviyede tutmak hem keratinositlerde hem vasküler sistemde gelecek hedefler arasındadır. ${ }^{11}$

5.6. Şiddetli kronik ağrının giderilmesi: Hastalarda karşılaşılan ağrının kontrolü diş hekimliği pratiğinde önem taşımaktadır. Gen tedavisi ile birlikte HSV tabanlı gen vektörleri, birincil nosiseptörleri (özelleşmiş sinir uçları) içeren ağrı aktarımının belirli bölgelerindeki nöraksislere direkt ulaşma kapasitesine sahiptir. Böylece sistemik ilaçların etki etmediği veya hedeflere açık olmayan bölgelere ulaşma olanağı sağlanmaktadır. HSV tabanlı gen tedavisinin, gen vektörleri tarafından sağlanan bütün nöronlara ulaşma yeteneği ile semptomları tedavi etme seçenekleri artırılmaktadır. ${ }^{11}$ Yapılan bir çalışmada fareler üzerinde tek seferde enjeksiyon yöntemi ile ensefalini kodlayan bir viral vektörün transgen ekspresyonu ve trigeminal davranışsal ağrı üzerine analjezik etkisi incelenmiş, viral vektörlerin direkt enjeksiyonunun trigeminal sistemin patofizyolojisi için faydalı olduğu bildirilmiştir. ${ }^{59}$

\section{Karşılaşılan sorunlar}

Gen tedavisi halen yeni bir tedavi alanı olarak kabul görmektedir ve risklerin tamamı ile gerçekleşebilecek sorunlara ilişkin detaylı bir bilgi bulunmamaktadır. Bu sorunlardan bazıları aşağıda sıralanmıştır:

6.1. Gen tedavisinin kısa ömürlü olması: Bir hastalıkta uygulanan gen tedavisinin kalıcı olabilmesi için, hedef hücrelere gönderilen terapötik DNA'ın fonksiyonel olarak kalması ve terapötik DNA içeren hücrelerin uzun ömürlü ve stabil olması istenmektedir. Birçok hücrenin hızlı bölünen doğası, gen tedavisinin uzun dönemde faydalı etkilerini engellemektedir. Bu nedenle gen tedavisi alan hastalar ile birçok seans çalışılmaktadır. Bunların yanı sıra yeni genlerin kendilerini eksprese etmelerinde başarısızlık göstermesi veya virüsün istenen yanıtı verememesi de sorun yaratmaktadır. ${ }^{7,11}$

6.2. Çoklu gen bozuklukları: Tek gen mutasyonuna bağlı bozukluklar gen tedavisi için en iyi aday konumundadırlar. Ancak yaygın olarak görülen kalp hastalığı, Alzheimer, diabet gibi hastalıklar için birçok aday gen bulunmaktadır. Çoklu gen bozukluklarında gen tedavisi zor olmaktadır. ${ }^{7}$

6.3. İmmun yanıt: İnsan vücuduna yabancı bir madde girdiğinde immun sistem bu maddeye karşı hareket geçmektedir. İmmun sistemin gen tedavisinin etkinliğini azaltması potansiyel riskler arasında yer almaktadır. ${ }^{7,11}$

6.4. Viral vektörler: Virüsler ile ilgili karşılaşılan sorunlar arasında hastalarda toksisite, immun ve inflamatuar yanıt meydana getirmesi, gen kontrolü ve dokuları hedeflemedeki başarısızıklar sayılabilmektedir. ${ }^{7,11}$

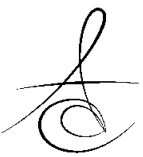


6.5. Mutagenezis eklenmesi: Virüslerin yanIış hücreleri hedef alması ile meydana gelebilen bir durumdur. Ör. DNA, genomun yanlış bölümüne entegre olduğu vakit tümörü suprese edeceği yerde tümör oluşturabilmektedir. ${ }^{7}$

\section{SONUÇ}

Pratikte tüm gen tedavileri için tek bir gen aktarımı yönteminin optimal olmadığı, spesifik uygulamalar için olabilecek en ideal metodun özellikleri arasında noninvaziv olması, hedef hücrelere ulaşma kapasitesinin yüksek olması ve istenen sürede uygun miktarda genetik materyal taşıyabilmesi istenmektedir.

$\mathrm{Bu}$ alanda önemli gelişmeler kaydedilmiş olmakla birlikte, insan üzerinde yapılan gen tedavilerinin başarısı için güvenli ve etkin yöntemlerin geliştirilmesi adına halen büyük çaba sarf edilmesine ihtiyaç duyulmaktadır.

Yelda Kasımoğlu: ORCID NO: 0000-0003-1022-2486 Mine Koruyucu: ORCID NO: 0000-0002-2077-5095 Figen Seymen: ORCID NO: 0000-0003-1713-0461

\section{KAYNAKLAR}

1. Miller DA. Human gene therapy comes of age. Nature 1992;375:455-60.

2. Friedmann T, Robin R. Gene therapy for human genetic disease? Science 1972;175:949-55.

3. Bayertz K, Paslack R, Schmidt KW. Summary of gene transfer into human somatic cells, state of the technology, medical risks, social and ethical problems: a report. Hum Gene Ther 1994;5:465-8.

4. Al-Dosari MS, Gao X. Nonviral gene delivery: principle, limitations, and recent progress. AAPS 2009;11:671-81.

5. Garcia-Godoy F, Murray P. Regenerative dentistry: translating advancements in basic science research to the dental practice. J Tenn Dent Assoc 2010;90:12-8.

6. Yayla M, Gül T, Görmüş $H$, Nazaroğlu H, Erden AC. Dicle Üniversitesi Tıp Fakültesi'ndeki doğumlarda konjenital anomali prevalansı: 6 yıllık seri. Zeynep Kamil Tıp Bülteni 1997;29:176-81.

7. Misra S. Human gene therapy: a brief overview of the genetic revolution. JAPI 2013;61:127-33.

8. Razi Soofiyani S, Baradaran B, Lotfipour F, Kazemi T, Mohammadnejad L. Gene therapy, early promises, subsequent problems, and recent breakthroughs. Adv Pharm Bull 2013;3:249-55.
9. Matthews QL, Curiel DT. Gene therapy human germline genetics modifications-assessing the scientific, socioethical, and religious issues. South Med J 2007; 100: 98-100.

10. Günel Özcan A. Gen tedavisi ve biyogüvenlik. Türk Hijyen ve Deneysel Biyoloji Dergisi 2007;64:35-50.

11. Gupta K, Singh S, Garg KN. Gene therapy in dentistry: Tool of genetic engineering. Revisited. Arch Oral Biol 2015; 60: 439-46.

12. Soofiyani SR, Baradaran B, Lotfipour F, Kazemi T, Mohammadnejad L. Gene therapy, early promises, subsequent problems, and recent breakthroughs. Adv Pharm Bull 2013; 3: 249-55.

13. Gardlik R, Paiffy R, Hodosy J, Lukacs J, Twrna J, Celec P. Vectors and delivery system in gene therapy. Med Sci Monit 2005; 11: 110-21.

14. Walter W, Stein U. Viral vectors for gene transfer: a review of their use in the treatment of human diseases. Drugs 2000; 60: 249-71.

15. Manjila SB, Baby JN, Bijin EN, Constantine I, Pramod K, Valsalakumari J. Novel gene delivery systems. Int J Pharm Investig 2013; 3: 1-7.

16. Baun C, Dullman J, Li Z, Fehse B, Meyer J, Williams $D A$, et al. Side effects of retroviral gene transfer into hematopoietic stem cells. Blood 2003; 101: 2099-114.

17. Wolff JA, Malone RW, Williams P, Chong W, Aesadi $G$, Jani $A$, et al. Direct gene transfer into mouse muscle in vivo. Science 1990;247:1465-8.

18. Pierce EA, Liu $Q$, Igouchera $O$, Dmarrudin $R, M a H$, Diamond $\mathrm{SL}$, et al. Oligonucleotide-directed single base DNA alteration in mouse embryonic stem cells. Gene Ther 2003;10:24-33.

19. Caplen NJ, Alton EW, Middleton PG, Dorin JR, Stevenson BJ, Gao X, et al. Liposome mediated CFTR gene transfer to a nasal epithelium of patient with cystic fibrosis. Nat Med 1995;1:39-46.

20. Huang S, Kamihira M. Development of hybrid viral vectors for gene therapy. Biotechnol Adv 2013; 31: 208-23.

21. Chaplot SP, Rupenthal ID. Dendrimers for gene delivery - a potential approach for ocular therapy? J Pharm Pharmacol 2014;66:542-56.

22. Kamimura K, Suda T, Zhang G, Liu D. Advances in gene delivery systems. Pharmaceut Med 2011;25: 293-306.

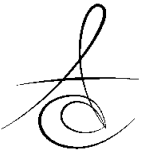


23. Kudyar N, Dani N, Mahale S. Periodontal vaccine: a dream or reality. J Indian Soc Periodontol 2011; 15: $115-20$.

24. Nakashima $M$, Tachibana $K$, Iohara $K$, Ito $M$, Ishikawa $M$, Akamine $A$. Induction of reparative dentin formation by ultrasound-mediated gene delivery of growth/differentiation factor 11 . Hum Gene Ther 2003; 14: 591-7.

25. Scheller EL, Krebsbach PH. Gene therapy: design and prospects for craniofacial regeneration. J Dent Res. 2009;88:585-96.

26. Özcan E, Atuğ Özcan SS. Periodontal rejenerasyonda kök hücrenin yeri. J Dent Fac Atatürk Uni 2010; 20:123-30.

27. Zhu W, Rawlins BA, Boachie-Adjei O, Myers ER,

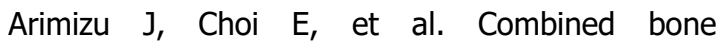
morphogenetic protein-2 and - 7 gene transfer enhances osteoblastic differentiation and spine fusion in a rodent model. J Bone Miner Res 2004; 19: 2021-32.

28. Cheng $\mathrm{H}$, Jiang W, Phillips FM, Haydon RC, Peng $Y$, Zhou $\mathrm{L}$, et al. Osteogenic activity of the fourteen types of human bone morphogenetic proteins (BMPs). J Bone Joint Surg Am 2003;85A:1544-52.

29. Yang $S$, Wei $D$, Wang $D$, Phimphilai M, Krebsbach $\mathrm{PH}$, Franceschi RT. In vitro and in vivo synergistic interactions between the Runx2/Cbfa1 transcription factor and bone morphogenetic protein-2 in stimulating osteoblast differentiation. J Bone Miner Res 2003;18:705-15.

30. Anusaksathien O, Jin Q, Zhao M, Somerman MJ, Giannobile WV. Effect of sustained gene delivery of platelet-derived growth factor or its antagonist (PDGF-1308) on tissue-engineered cementum. J Periodontol 2004;75:429-40.

31. Jin Q, Anusaksathien O, Webb SA, Printz MA, Giannobile WV. Engineering of tooth-supporting structures by delivery of PDGF gene therapy vectors. Mol Ther 2004;9:519-26.

32. Kaigler D, Mooney D. Tissue engineering's impact on dentistry. J Dent Educ 2001;65:456-62.

33. Dunn CA, Jin Q, Taba M Jr, Franceschi RT, Bruce Rutherford R, Giannobile WV. BMP gene delivery for alveolar bone engineering dental implant defects. Mol Ther 2005;11:294-9.

34. Chatterjee A, Singh N, Saluja M. Gene therapy in periodontics J Indian Soc Periodontol 2013;17:15661.
35. Fliefel R, Kühnisch J, Efrenfeld M, Otto S. Gene therapy for bone defects in oral and maxillofacial surgery: a systematic review and meta-analysis of animal studies. Stem Cells Dev 2017;26:215-30.

36. Okawa R, Iijima O, Kishino M, Okawa H, Toyosawa S, Sugano-Tajima H, Shimada T, Okada T, Ozono K, Ooshima T, Nakano K. Gene therapy improves dental manifestations in hypophosphatasia model mice. J Periodontal Res 2017;52:471-8.

37. Gurunathan S, Klinman DM, Seder RA. DNA vaccines: immunology, application, and optimization. Annu Rev Biochem. 2000;18:927-974.

38. Barackman JD, Ott G, O'Hagan DT. Intranasal immunization of mice with influenza vaccine in combination with the adjuvant LT-R72 induced potent mucosal and serum immunity which is stronger than that with traditional intramuscular immunization. Infec Immun 1999; 67: 4276-9.

39. Zhou X, Zhang X, Yu X, Zha X, Fu Q, Liu B, et al. The effect of conjugation to gold nanoparticles on the ability of low molecular weight chitosan to transfer DNA vaccine. Biomaterials 2008;29:111-7.

40. Wang $X$, Zhang $X$, Kang $Y$, Jin H, Du X, Zhao G, et al. Interleukin-15 enhance DNA vaccine elicited mucosal and systemic immunity against foot and mouth disease virus. Vaccine 2008;26:5135-44.

41. Khatri K, Goyal AK, Gupta PN, Mishra N, Mehta A, Vyas SP. Surface modified liposomes for nasal delivery of DNA vaccine. Vaccine 2008;26:2225-33.

42. Chen L, Zhu J, Li Y, Lu J, Gao L, Xu H, et al. Enhanced nasal mucosal delivery and immunogenicity of anti-caries DNA vaccine through incorporation of anionic liposomes in chitosan/DNA complexes. PLoS One 2013;8:e71953.

43. Waterhouse JC, Russell RR. Dispensable genes and foreign DNA in Streptococcus mutans. Microbiology 2006;152:1777-88.

44. Cui Z. DNA vaccine. Adv Genet. 2005;54:257-89.

45. Coombes BK, Mahony JB. Dendritic cell discoveries provide new insight into the cellular immunobiology of DNA vaccines. Immunol Lett 2001;78:103-11.

46. Liu S, Gong Q, Wang C, Liu H, Wang Y, Guo S, et al. A novel DNA vaccine for protective immunity against virulent Mycobacterium bovis in mice. Immunol Lett 2008;117:136-45. 
47. Xu QA, Yu F, Fan MW, Bian Z, Chen Z, Fan B, et al. Immunogenicity and persistence of a targeted anti-caries DNA vaccine. J Dent Res 2006; 85: 9158.

48. Liu S, Chen P, Hu M, Tao Y, Chen L, Liu H, et al. Randomized, controlled phase II study of postsurgery radiotherapy combined with recombinant adenoviral human p53 gene therapy in treatment of oral cancer. Cancer Gene Ther 2013;20:375-8.

49. Mcwilliams JE, Evans AJ, Beer TM, Anderson PE, Cohen JI, Everts EC, et al. Genetic polymorphisms in head and neck cancer risk. Head Neck 2000;22: 609-17.

50. Searle PF, Chen MJ, Hu L, Race PR, Lovering AL, Grove JI, et al. Nitroreductase: a prodrugactivating enzyme for cancer gene therapy. Clin Exp Pharmacol Physiol 2004;31:811-6.

51. Kershaw MH, Teng MW, Smyth MJ. Supernatural T cells: genetic modification of $\mathrm{T}$ cells for cancer therapy. Nat Rev Immunol 2005; 5:928-40.

52. Steel JC, Di Pasquale G, Ramiogan CA, Patel V, Chiorini JA, Morris JC. Oral vaccination with adenoassociated virus vectors expressing the $\mathrm{Neu}$ oncogene inhibits the growth of murine breast cancer. Mol Ther 2013; 21:680-7.

53. Singh R, Singh S, Kumar T, Kumar A, Kumar A, Nazeer J. A novel approach in the treatment of oral cancer-gene therapy an update. World J Pharm Pharm Sci 2017;6:283-9.

54. Aframian DJ, Palmon A. Current status of the development of an artificial salivary gland. Tissue Eng Part B Rev 2008;14:187-98.

55. Cotrim AP, Mineshiba F, Sugito T, Samuni Y, Baum BJ. Salivary gland gene therapy. Dent Clin North Am 2006; 50:157-73.

56. Geguchadze R, Wang Z, Zourelias L, Perez-Riveros $P$, Edwards $P C$, Machen $L$, Passineau $M J$. Proteomic profiling of salivary gland after nonviral gene transfer mediated by conventional plasmids and minicircles. Mol Ther Methods Clin Dev 2014;1:14007.

57. Paramel Mohan Sunil, Ramachandran $C R$, Jaisanghar N, Santhosh Kumar C. Dental surgeons as gene therapist. Int J Oral Maxillofac Pathol 2012; 3:65-7.

58. Jonathan CV. Keratinocyte gene therapy. Arch Dermatol 1993;129:1478-83.
59. Tzabazis AZ, Klukinov M, Feliciano DP, Wilson SP, Yeomans DC. Gene therapy for trigeminal pain in mice. Gene Therapy 2014;21:422-6.

\section{Yazışma Adresi}

Dr. Yelda Kasımoğlu

İstanbul Üniversitesi,

Diş Hekimliği Fakültesi

Pedodonti Anabilim Dalı, 34093-İstanbul, Türkiye

Fax: 02125310515

Tel: $02124142020-30400$

e-mail: yelda.kasimoglu@istanbul.edu.tr 